\title{
Influence of Growth Regulators on Quality and Fruit Attributes of Custard Apple (Annona squamosa L.) CV. Balanagar
}

\author{
U. K. Thorat, R. M. Dheware and A. R. Jadhav
}

Dept. of Horticulture, College of Agriculture, Latur. Vasantrao Naik Marathwada Krishi Vidyapeeth, Parbhani, M.S. (431402), India

\section{Corresponding Author}

R. M. Dheware

e-mail: rmdheware123@gmail.com

\author{
Article History \\ Article ID: IJEP0245 \\ Received in $12^{\text {th }}$ March, 2018 \\ Received in revised form $22^{\text {nd }}$ July, 2018 \\ Accepted in final form $17^{\text {th }}$ August, 2018
}

\begin{abstract}
The field study was conducted on a well-established custard apple orchard of eight years age at Custard Apple Research Station, Ambajogai, Dist. Beed, during 2016-17, to study the influence of growth regulators on quality and fruit attributes of custard apple (Annona squamosa L.) Cv. Balanagar. The experiment framed was concentrated to find out effective concentration of $\mathrm{GA}_{3}$ and NAA as well as their combination for getting high quality of custard apple fruits.The maximum length of fruit, diameter of fruit, weight of pulp, weight of peel was recorded under the treatment $\mathrm{T}_{7}\left(\mathrm{GA}_{3} 25+\mathrm{NAA} 10 \mathrm{ppm}\right)$. In present study, it had been observed that the foliar application of growth regulators was found beneficial for increasing quality of custard apple fruits. While, the combine spraying of $\mathrm{GA}_{3} 25+\mathrm{NAA} 10 \mathrm{ppm}$ twice i.e. before flowering (second fortnight of may) and one month after the first spray is beneficial for getting higher quality of custard apple Cv. 'Balanagar' under Marathwada region of Maharashtra.
\end{abstract}

Keywords: Growth regulators, quality, fruit attributes, custard apple

\section{Introduction}

Custard apple (Annona squamosa L.) is the most ancient dry land fruit crop in India. It was originated from tropical region of America and widely distributed throughout the tropics and subtropics. In India, the area under custard apple cultivation is about 35000 ha with the production of 271000 MT. Out of these Maharashtra state contributes 8660 ha area with $59300 \mathrm{mt}$ productions (Anonymous, 2016). The plant growth regulators are effective at very low concentration, hence they are cost effective. Presently growth regulators are given considerable importance for their value in regulating the various growth and development processes in plants. The plant growth regulator like $\mathrm{GA}_{3}$ is also useful to increase the fruit setting per branch, number of fruits per tree, fruit weight and ultimately increase the fruit yield (Shinde et al., 2008). Application of NAA checks the fruit drop and thereby increased the fruit retention, fruit weight and TSS of the fruits (Singh and Chohan, 1984).

\section{Materials and Methods}

A field trial on custard apple Cv. Balanagar was conducted at Custard Apple Research Station, Ambajogai, Dist. Beed, during 2016-17. The 8 year old plants grown at $4 \times 4 \mathrm{~m}^{2}$ spacing were used for the experiment. The experiment was laid out in a Randomized Block Design with 10 treatments viz., $T_{1}$ : GA
25 ppm, $\mathrm{T}_{2}: \mathrm{GA}_{3} 50$ ppm, $\mathrm{T}_{3}: \mathrm{GA}_{3} 75$ ppm, $\mathrm{T}_{4}:$ NAA 10 ppm, $\mathrm{T}_{5}$ : NAA $20 \mathrm{ppm}, \mathrm{T}_{6}$ : NAA $30 \mathrm{ppm}, \mathrm{T}_{7}: \mathrm{GA}_{3} 25$ + NAA $10 \mathrm{ppm}$, $\mathrm{T}_{8}: \mathrm{GA}_{3}$ 50+NAA $20 \mathrm{ppm}, \mathrm{T}_{9}: \mathrm{GA}_{3} 75+\mathrm{NAA} 30 \mathrm{ppm}$ and $\mathrm{T}_{10}$ : control (water spray) with three replications. The statistical analysis of the data in respect of quality and fruit attributes was done according to the standard procedure given by Panse and Sukhatme (1985).

\section{Results and Discussion}

\subsection{Influence on quality attributes}

The different treatments of foliar application of growth regulators showed (Table 1) positive response on quality attributes of custard apple fruit. The maximum value of TSS (25.29\%) was recorded in the treatment $\mathrm{T}_{8}\left(\mathrm{GA}_{3} 50+\mathrm{NAA} 20\right.$ ppm). These findings are also supported by result obtained by Ghosh et al. (2009) in pomegranate and Rawatet al. (2015) in aonla. The results revealed that significantly maximum reducing sugar $(20.18 \%)$, non-reducing sugar $(2.07 \%)$ and total sugars were recorded in the treatment $\mathrm{T}_{9}\left(\mathrm{GA}_{3} 75+\mathrm{NAA}\right.$ $30 \mathrm{ppm})$. These results controversy reported by Srivastava et al. (2009) in aonla and Prajapatiet al. (2016) in custard apple. Acidity of fruit was not significantly influenced due to application of plant growth regulators. However, it was maximum $(0.27 \%)$ in the treatment $\mathrm{T}_{10}$ i.e. control (water spray). While, it was minimum $(0.22 \%)$ in the treatment $T_{7}$ 


\begin{tabular}{lccccc}
\hline \multicolumn{6}{l}{ Table 1: Influence on quality attributes } \\
\hline $\begin{array}{l}\text { Treat- } \\
\text { ments }\end{array}$ & $\begin{array}{c}\text { TSS } \\
(\%)\end{array}$ & $\begin{array}{c}\text { Acidity } \\
(\%)\end{array}$ & $\begin{array}{c}\text { Reducing } \\
\text { sugar (\%) }\end{array}$ & $\begin{array}{c}\text { Non- } \\
\text { reducing } \\
\text { sugar } \\
(\%)\end{array}$ & $\begin{array}{c}\text { Total } \\
\text { sugar } \\
(\%)\end{array}$ \\
\hline $\mathrm{T}_{1}$ & 23.17 & 0.23 & 19.40 & 1.92 & 21.32 \\
$\mathrm{~T}_{2}$ & 23.50 & 0.29 & 17.80 & 1.76 & 19.56 \\
$\mathrm{~T}_{3}$ & 19.52 & 0.31 & 14.10 & 1.44 & 15.54 \\
$\mathrm{~T}_{4}$ & 18.00 & 0.29 & 13.87 & 1.39 & 15.26 \\
$\mathrm{~T}_{5}$ & 22.61 & 0.27 & 16.75 & 1.69 & 18.44 \\
$\mathrm{~T}_{6}$ & 21.80 & 0.23 & 16.14 & 1.63 & 17.77 \\
$\mathrm{~T}_{7}$ & 24.03 & 0.22 & 15.27 & 1.58 & 16.85 \\
$\mathrm{~T}_{8}$ & 25.29 & 0.25 & 15.20 & 1.61 & 16.81 \\
$\mathrm{~T}_{9}$ & 20.40 & 0.24 & 20.18 & 2.07 & 22.25 \\
$\mathrm{~T}_{10}$ & 17.68 & 0.27 & 12.60 & 1.37 & 13.97 \\
$\mathrm{SEm} \pm$ & 2.02 & 0.02 & 0.67 & 0.09 & 0.68 \\
$\mathrm{CD}$ & 5.44 & 0.06 & 1.99 & 0.28 & 2.03 \\
$(p=0.05)$ & & & & & \\
\hline
\end{tabular}

$\left(\mathrm{GA}_{3} 25+\mathrm{NAA} 10 \mathrm{ppm}\right)$. The results are in agreement with the findings with Srivastava et al. (2009) in aonla, Memane and Pujari (2013) in custard apple and Osama et al. (2015) in mango.

\subsection{Influence on fruit attributes}

The data revealed from (Table 2) the significant variations in the physical attributes of custard apple fruits viz., fruit length, fruit diameter, weight of pulp, weight of peel, seed to pulp ratio, peel (\%), number of seed, weight of seed and fruit volume were observed. The maximum fruit length $(9.10 \mathrm{~cm})$ and fruit diameter $(8.65 \mathrm{~cm})$ was noted under the treatment $\mathrm{T}_{7}$ $\left(\mathrm{GA}_{3} 25+\mathrm{NAA} 10 \mathrm{ppm}\right)$ as compared to control. The results are in close conformity with findings of Reddy and Prasad (2011) in pomegranate. The maximum weight of pulp $(90.56 \mathrm{~g})$ and weight of peel (110.20 g) were recorded underthe treatment $\mathrm{T}_{7}\left(\mathrm{GA}_{3} 25+\mathrm{NAA} 10 \mathrm{ppm}\right)$. Minimum values of most of these attributes were observed in control $\left(T_{10}\right)$. These findings are also supported by the results obtained by Brahmachari and Kumar (1997) in Guava. Also Katiyar et al. (2010) in Ber. The seed to pulp ratio, per cent of peel, number of seeds, weight of seeds and fruit volume were found significant by the application of plant growth regulators. The results are

\begin{tabular}{|c|c|c|c|c|c|c|c|c|c|}
\hline Treatments & $\begin{array}{l}\text { Fruit length } \\
\qquad(\mathrm{cm})\end{array}$ & $\begin{array}{l}\text { Fruit diameter } \\
\qquad(\mathrm{cm})\end{array}$ & $\begin{array}{l}\text { Wt. of pulp } \\
\text { (g) }\end{array}$ & $\begin{array}{l}\text { Wt. of } \\
\text { peel (g) }\end{array}$ & $\begin{array}{l}\text { Seed: } \\
\text { pulp } \\
\text { ratio }\end{array}$ & $\begin{array}{c}\text { Percent } \\
\text { of peel } \\
(\%)\end{array}$ & $\begin{array}{l}\text { No. of } \\
\text { seeds } \\
\text { (No.) }\end{array}$ & $\begin{array}{l}\text { Wt. of } \\
\text { seeds } \\
\text { (g) }\end{array}$ & $\begin{array}{l}\text { Fruit } \\
\text { volume } \\
\text { (cc) }\end{array}$ \\
\hline $\mathrm{T}_{1}$ & 5.44 & 4.60 & 71.92 & 90.16 & 0.37 & 47.69 & 42 & 26.96 & 155.08 \\
\hline $\mathrm{T}_{2}$ & 7.80 & 7.30 & 81.33 & 102.04 & 0.29 & 49.40 & 38 & 23.19 & 166.12 \\
\hline$T_{3}$ & 6.90 & 6.10 & 73.18 & 93.26 & 0.35 & 48.42 & 41 & 26.16 & 157.90 \\
\hline $\mathrm{T}_{4}$ & 7.56 & 7.00 & 76.80 & 95.72 & 0.32 & 48.49 & 39 & 24.90 & 161.50 \\
\hline$T_{5}$ & 8.80 & 8.04 & 85.21 & 107.31 & 0.24 & 50.23 & 34 & 21.12 & 174.92 \\
\hline $\mathrm{T}_{6}$ & 8.94 & 8.46 & 87.12 & 108.60 & 0.23 & 50.25 & 33 & 20.36 & 177.70 \\
\hline $\mathrm{T}_{7}$ & 9.10 & 8.65 & 90.56 & 110.20 & 0.21 & 50.00 & 31 & 19.64 & 180.87 \\
\hline $\mathrm{T}_{8}$ & 8.21 & 7.85 & 83.67 & 104.52 & 0.26 & 49.72 & 35 & 22.01 & 172.10 \\
\hline $\mathrm{T}_{9}$ & 7.18 & 6.70 & 75.00 & 95.08 & 0.33 & 48.73 & 41 & 25.02 & 160.00 \\
\hline $\mathrm{T}_{10}$ & 4.86 & 4.23 & 68.06 & 91.12 & 0.40 & 48.18 & 43 & 27.88 & 145.16 \\
\hline SEm \pm & 0.41 & 0.50 & 3.11 & 3.21 & 0.03 & 2.16 & 2.54 & 1.56 & 5.33 \\
\hline $\mathrm{CD}(p=0.05)$ & 1.23 & 1.50 & 9.26 & 9.53 & 0.11 & 6.42 & 7.56 & 4.66 & 15.86 \\
\hline
\end{tabular}

in agreement with the findings with Garasiya et al. (2013) in guava and Prajapati et al. (2016) in custard apple.

\section{Conclusion}

In the light of the results obtained from this investigation, it can be inferred that spraying of GA3 25+NAA 10 ppm twice i.e. before flowering (second fortnight of may) and one month after the first spray is beneficial for getting higher physical fruit attributes of custard apple and maximum quality recorded in high concentration of $\mathrm{GA}_{3}$ and NAA under Marathwada region of Maharashtra. As the results of the present investigation are based on one season data, further detailed experimentations are necessary to confirm findings.

\section{References}

Anonymous. (2016). Ministry of Agriculture and Farmer Welfare, Government of India.

Brahmachari, V.S., Kumar, N., Kumar, R., 1997. Effect of foliar feeding of calcium, potassium and growth substance on yield and quality of guava (Psidium guajava L.). Haryana 
Journal Of Horticultural Sciences 26(3-4), 169-173.

Garasiya, V.R., Patel, N.M., Bhadauria, H.S., Wankhade, V.R., 2013. Studies of plant growth substances on the yield component of winter season guava CV. L-49. International Journal of Agricultural Sciences 9(1), 114-116.

Ghosh, S.N., Bera, B., Roy, S., Kundu, A., 2009. Effect of plant growth regulators in yield and fruit quality in pomegranate Cv. Ruby. Journal of Horticultural Science 4 (2), 158-160.

Katiyar, P.N., Yadhav, V., Singh, J.P., 2010. Effect of preharvest spray of NAA and $\mathrm{GA}_{3}$ on fruiting, fruit quality and yield of ber (Zizyhus mauritiana) Cv. Banarasi Karaka. Annals of Horticulture 3(1), 92-94.

Memane, Y.S., Pujari, C.V., 2013. Effect of different plant growth regulators on fruit set, yield and quality of custard apple (Annona squamosa, L), M.Sc. Thesis submitted to MPKV Rahuri.

Osama, H.M., Amro, S.M., Saber, S., Bakeer, M.M., 2015. Effect of growth regulator on fruiting and fruit quality of mango trees. Cv. Keitt. IOSR Journal of Agriculture and veterinary Science 8(12), 87-95.

Panse, V.G., Sukhatme, P.V., 1985. Statistical Methods for Agricultural Workers. I.C.A.R., New Delhi, 145-156.

Prajapati, R.D., Laua, H.N., Solanki, P.D., Parekh, N.S., 2016.
Effect of plant growth regulators on flowering, fruiting, yield and quality parameters of custard apple (Annona squmosa L.). Ecology, Environment and Conservation 22, 177-179.

Rawat, S.S., Chandra, R., Manju and Singh, K.K., 2015. Effect of foliar application of growth regulators on yield and quality of anola Cv. NA-7. International Journal of Tropical Agriculture, 33(1).

Reddy, P., Prasad Manohar, D., 2011. Effect of plant growth regulators on fruit characters and yield of pomegranate (Punica granatum L.) Cv. Ganesh. Internation J. of plant, animal and environmental sciences 2(2), 91-93.

Shinde, B.B., Ingle, H.V., Dhawale, D.U., Hajare, A.R., Dhobe, S.G., 2008. Effect of plant growth regulators on size, yield and quality of acid lime. Journal of Soils \& Crops 18(1), 117-120.

Singh, M.I., Chohan, G.S., 1984. Effect of various plant growth regulators on granulation in citrus $\mathrm{Cv}$. Dancy Tangerine. Indian Journal of Horticulture 41(3-4), 221-224.

Srivastava, C.P., Singh, H.K., Vishwanath and Bhanu, P., 2009. Efficacy of foliar feeding of plant growth regulators along with urea on yield and quality of aonla (Emblica officinalis Gaertn.) Cv. NA-7 fruits. Annals of Horticulture 2(1), 77-79. 